\title{
Can eDNA metabarcoding offer a catchment-based approach for biodiversity monitoring?
}

\author{
Laura Allen $\ddagger$ $\S$, Martin Wilkes $\ddagger$, Marco Van De Wielł, Mike Morris§, Alex J Dumbrell, Alessia Banil \\ $\ddagger$ Coventry University, Coventry, United Kingdom \\ $\S$ Severn Rivers Trust, Worcester, United Kingdom \\ | Essex University, Essex, United Kingdom
}

\begin{abstract}
Corresponding author: Laura Allen (laura.allen@severnriverstrust.com),
Martin Wilkes (ab9323@coventry.ac.uk), Marco Van De Wiel (ab9182@coventry.ac.uk),

Mike Morris (mike@severnriverstrust.com), Alex J Dumbrell (adumb@essex.ac.uk),

Alessia Bani (ab18858@essex.ac.uk)

Received: 08 Mar 2021 | Published: 08 Mar 2021

Citation: Allen L, Wilkes M, Van De Wiel M, Morris M, Dumbrell AJ, Bani A (2021) Can eDNA metabarcoding

offer a catchment-based approach for biodiversity monitoring? ARPHA Conference Abstracts 4: e65651.

https://doi.org/10.3897/aca.4.e65651
\end{abstract}

\begin{abstract}
In previous studies eDNA metabarcoding has been demonstrated as a viable tool for catchment-level biodiversity sampling in rivers (Deiner et al. 2016). However, questions still remain over the appropriate sampling protocol for large spatial scale sampling. River reaches are composed of multiple habitats with species composition varying from one to the next (Costa and Melo 2007). Therefore, how many spatial replicates are needed to reliably represent the river network? Is the previously used approach to sample at every river confluence (Deiner et al. 2016) sufficient or is more needed? These questions were addressed using a case study in the headwaters of the Cound Brook, a tributary to the River Severn in Shropshire, UK.

Two sub-catchments of the Cound Brook were used. One sub-catchment had a sample taken at the most downstream point before the confluence. Additionally, a sample at the upstream extent of the same sub-catchment was taken to estimate any correlation between the species found at the beginning of the river reach and at the end. Another subcatchment also had the same up- and downstream sample design. However, in between
\end{abstract}


was a systemic sampling regime every $500 \mathrm{~m}$. This is to test if increasing the spatial resolution gave significantly different results to the sparser sampling regime.

At each sample location, a $1 \mathrm{~L}$ water sample was sequentially filtered through membranes of three different mesh sizes: $5 \mu \mathrm{m}, 0.45 \mu \mathrm{m}$ and $0.2 \mu \mathrm{m}$. Sequential filtering was performed because DNA resides in two forms in the environment (Civade et al. 2017), within whole cells (cellular DNA) and outside of cells (extracellular). The theory is that the coarser filters predominantly collect cellular DNA and the finer filters collect predominantly extracellular DNA of increasingly smaller fragment lengths. Consequently, sequential filtering could represent DNA degradation in the environment (Fig. 1). Also, Turner et al. 2014 suggested that the larger particles could determine very recent or local organisms. Therefore, we hypothesised that the DNA collected by the coarser filters would represent local diversity and the DNA collected by the finer filters would reflect biodiversity further upstream.

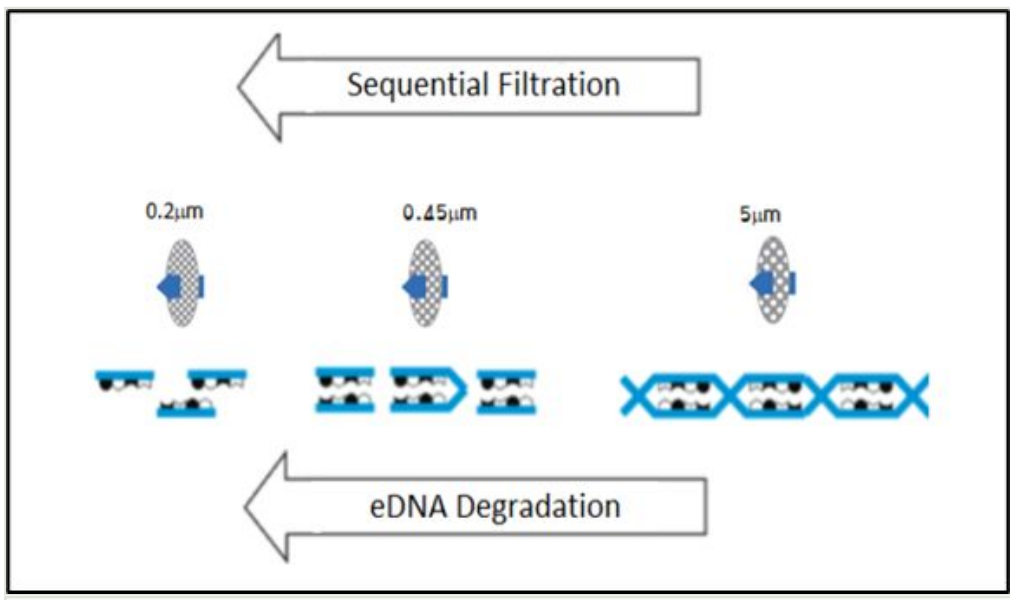

Figure 1. doi

Figure 1: Illustration of the theory that sequential filtering reflects eDNA degradation in the environment.

Initial results suggest sequential filtering through the $5 \mu \mathrm{m}$ and $0.45 \mu \mathrm{m}$ filters caught detectable levels of eDNA where the $0.2 \mu \mathrm{m}$ did not catch enough to show up through gel electrophoresis. The relevance of the initial finding suggests that if we only used a $5 \mu \mathrm{m}$ filter the data collected at $0.45 \mu \mathrm{m}$ could have been discarded. Further investigations of any differences in species compositions between filters and the relationships to other sampling locations is still to be determined. This ongoing research is intended to determine the appropriate sampling protocol for a large-scale biodiversity assessment regime combining eDNA metabarcoding and species distribution modelling.

\section{Keywords}

eDNA Metabarcoding, Sequential filtering, Sampling regime, Catchment, River 


\section{Presenting author}

Laura Allen

\section{Presented at}

1st DNAQUA International Conference (March 9-11, 2021)

\section{References}

- $\quad$ Civade R, Dejean T, Valentini A, Roset N, Raymond J, Bonin A, Taberlet P, Pont D (2017) Spatial representativeness of environmental DNA metabarcoding signal for fish biodiversity assessment in a natural freshwater system. PLOS ONE 11 (6).

- Costa S, Melo AS (2007) Beta diversity in stream macroinvertebrate assemblages: among-site and among-microhabitat components. Hydrobiologia 598 (1): 131-138.

- Deiner K, Fronhofer E, Mächler E, Walser J, Altermatt F (2016) Environmental DNA reveals that rivers are conveyer belts of biodiversity information. ETH Zurich https:// doi.org/10.3929/ethz-b-000121528

- Turner C, Barnes M, Xu C, Jones S, Jerde C, Lodge D (2014) Particle size distribution and optimal capture of aqueous macrobial eDNA. Methods in Ecology and Evolution 5 (7). 